\title{
Rock Slope Stability Analysis based on Terrestrial LiDAR on Karst Hills in Kinta Valley Geopark, Perak, Peninsular Malaysia
}

(Analisis Kestabilan Cerun Batuan berdasarkan LiDAR Daratan di Bukit Batu Kapur

Geotaman Lembah Kinta, Perak, Semenanjung Malaysia)

\author{
Muhammad Afiq Ariff Hellmy, Ros Fatihah MuHammad*, Mustaffa Kamal Shuib, Ng Tham Fatt, \\ WAN HASIAH ABDULlaH, AishaH ABU BAKAR \& RALPH KUGLER
}

\section{ABSTRACT}

The use of modern mapping technology is necessary in assessing slopes and cliffs, especially in tropical countries as it is mostly inaccessible and covered with thick vegetation which restricts the conventional data collection to only at the base of the cliff. Overhanging and sub-vertical characteristics of tropical karst hills in Kinta Valley together with highly fractured and day-lighting joints increase the possibility of rock slope failure. The problem statement of this research is how Terrestrial Laser Scanning (TLS) can assist the traditional survey in slope characterization. The main objective of this research was to assess the stability of the limestone hills in Kinta Valley based on the output provided by terrestrial LiDAR and scanline survey method. TLS helps engineers and geologists to collect a high number of discontinuity data where it is inaccessible for manual compass data measurement. A total number of about 13 cliffs on 4 limestone hills were assessed. Gunung Lang and Kek Lok Tong show major potential failure trending towards east, Gunung Lanno towards southwest, Kwan Yin Tong towards west, and Gunung Cheroh with three directions of failure which are pointed towards the south, southwest and southeast direction. The overall results showed that the orientation of the major joint sets and the direction of the failure greatly influence the karst hills morphology in the Kinta Valley. The integration of LiDAR method with the manual compass clinometer has become a better approach to assess the stability of limestone hills and other rock slope in the possible future.

Keywords: Limestone hills; slope stability; terrestrial laser scanning

\section{ABSTRAK}

Penggunaan teknologi pemetaan moden ialah satu keperluan dalam menilai cerun dan tebing terutamanya di negara tropika kerana kebanyakan kawasannya tidak boleh diakses dan diliputi oleh tumbuhan yang tebal yang mengehadkan pengumpulan data secara konvensional yakni pada bahagian bawah cerun sahaja. Ciri gunung batu kapur tropika yang curam dan sub-menegak di Lembah Kinta bersama dengan retakan teruk dan satah yang mengarah keluar dari cerun meningkatkan kecenderungan kegagalan cerun batuan. Pernyataan masalah kajian ini adalah bagaimana LiDAR daratan boleh membantu tinjauan tradisi dalam pencirian cerun. Objektif utama penyelidikan ini adalah untuk menilai kestabilan gunung batu kapur di Lembah Kinta berdasarkan output yang disediakan oleh LiDAR daratan dan kaedah tinjauan garis imbasan. Imbasan laser terestrial (TLS) membantu jurutera dan ahli geologi mengumpul data ketakselanjaran dalam bilangan yang tinggi di kawasan yang tidak dapat diakses untuk pengukuran data secara manual oleh kompas klinometer. Sebanyak tiga belas cerun daripada empat gunung batu kapur telah dinilai. Gunung Lang dan Kek Lok Tong menunjukkan tren jatuhan ke arah timur, Gunung Lanno ke arah barat daya, Kwan Yin Tong ke arah barat dan Gunung Cheroh ke arah selatan, barat daya dan tenggara. Keputusan keseluruhan menunjukkan orientasi utama kekar dan arah jatuhan batuan mempengaruhi morfologi gunung karst di Lembah Kinta. Integrasi LiDAR dan kompas klinometer secara manual merupakan pendekatan yang baik untuk menilai kestabilan gunung batu kapur dan cerun batuan lain pada masa hadapan.

Kata kunci: Bukit batu kapur; imbasan laser terestrial; kestabilan cerun

\section{INTRODUCTION}

Rock slope stability analysis has been used for decades in monitoring exposed rock slope to evaluate their potential hazard. The mechanical behaviour of rock masses is determined by the geometry of the slopes and the discontinuity properties. Therefore, detailed information of the discontinuity properties such as dip angle, strike, dip direction, roughness, persistency and spacing of the joints present within the rock mass were observed for kinematic analysis and rockfall prediction.

Traditional discontinuity measurements such as scanline survey, cell mapping, and geologic structure mapping have several major disadvantages (Priest 1993; Priest \& Hudson 1981). Scanline measurement technique 
is a commonly applied and well established method. However, it is time consuming and relies on visual inspections and direct measurements by the researchers. This results in biased data which are based on the skill level and knowledge of the researchers concerning the rock discontinuity properties and resultant ratings (Lato \& Vöge 2012). This technique also directly exposes the researchers to potential rockfall impacts during the survey. Furthermore, discontinuities on the upper part of the slope were unreachable via scanline technique.

Recent advancements in remote sensing technology through the 2000s have resulted in the widespread use of these technologies in geotechnical field and slope monitoring (Agliardi \& Crosta 2003; Guzzetti et al. 2004; Marquinez et al. 2003). 3D Terrestrial Laser Scanner (3D TLS) is one of the examples of remote sensing that has been used in slope monitoring and analysis of rock face structure (Dunning et al. 2009; Sturzenegger \& Stead 2009). 3D TLS provides denser, rapid and safe rock mass discontinuity measurements. Discontinuity properties such as dip angle and dip direction of the joints which may be unreachable by scanline technique can be quickly scanned and extracted from the 3D Digital Terrain Model (DTM) created by 3D TLS. These data can be processed for rock slope stability analysis input.

Rock mass discontinuity studies is an important key element for the stability of the slopes, especially on steep sided rock slopes such as in Kinta Valley limestone hills. Kinta Valley is well known for its fascinating karst landscape and steep sided limestone hills protruding from alluvial plain. Since the site has been proposed as a National Geopark, further detailed studies are required on karst cliff among the geosites as shown in Figure 1. The karst in the study area was formed from Kinta Limestone of the Silurian to Lower Permian age. The hills are made up of pure crystalline limestone and are invariably marmorised due to granite intrusions; they mostly lack of fossils (Ingham $\&$ Bradford 1960). The valley is formed in between two granitic highlands in the east and west from which the thick alluvium was derived. Limestone hills are commonly being dissected with geological structures such as joints and faults, together with the bedding planes of the limestones. These structures control the formation of karstic features and the morphology of the limestone hills in Kinta Valley (Tan 1988). According to Norbert et al. (2015), most of the limestone hills in Kinta Valley are mainly characterised by adverse structural conditions and day lighting blocks. Reports on stability analysis of limestone hills in Kinta Valley have been done by many researchers recently. By studying lineaments from aerial photographs, the formation of dolines are determined to be majorly controlled by the joints orientation presence in the area (Muhammad \& Tjia 2003). Rock collapse and failure plays a major role in the formation of the dolines in the area. According to Norbert et al. (2015), based on the seven components in the RMS system, Gunung Rapat, Gunung Datok, and Gunung Lang are classified as weak while other hills are classified as moderate. Another method used in assessing the limestone

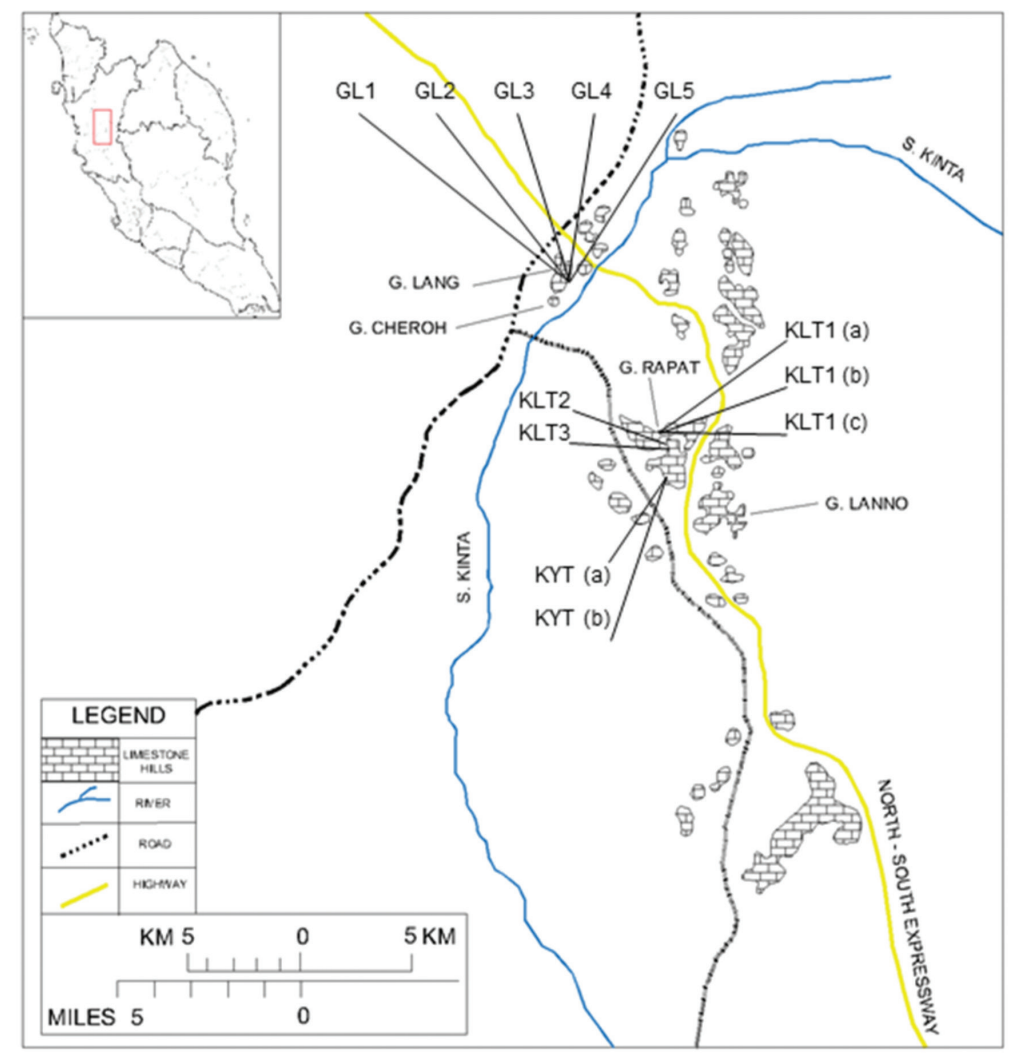

FIGURE 1. Map showing wide spread of limestone hills and the location of the study area 
hills is the Slope Mass Rating, SMR (Romana 1985) method by Goh et al. (2016).

Based on their study, the rock slopes at Gunung Lang are stable to unstable with the probability of failure ranging from 0.2 to 0.6 , respectively. Another study of SMR was also done by Ghani et al. (2018) on 53 cross sections at Gunung Kandu hill slopes. The assessment showed that the stability of the western flanks can be classified as stable to unstable with the probability of failure from 0.2 to 0.6 . The stability of the eastern and southern flanks ranges from very stable to partially stable with the probability of failure from 0.0 to 0.4 , while the stability of northern flanks is from very stable to stable with the probability of failure of $0.0-0.2$ (Ghani et al. 2018). There is also a study on geomechanical strength of carbonate rock in Kinta Valley by using uniaxial compressive strength test, point load test, and Brazilian tensile test (Nur Amanina et al. 2018).

Based on the test, the results showed that the geomechanical strengths of rock material of carbonate rocks for material and discontinuities failure deteriorates approximately $1 / 2$ from material failure (Nur Amanina et al. 2018) which means carbonate rocks in the area have low geomechanical strength. A study of lineament density shows a good correlation between lineament density map and the RMS score (Ghani et al. 2016).

\section{MATERIALS AND METHODS}

The objective of this study was to apply 3D TLS to remotely assess the slopes and complement the previous data. The new information obtained from the inaccessible height of the karst slopes is used to interpret the structural elements that may have controlled the formation of karst hills in Kinta Valley and their morphology.

A total number of 4 limestone hills and 13 rock slope faces are selected for this research based on slope accessibility and safety near the man-made structure. A few of these sites are geosites within the Kinta Valley National Geopark. The cliff faces are GL1, GL2, GL3, GL4, GL5 in Gunung Lang, KLT 1 (a), KLT 1 (b), KLT 1 (c), KLT 2, KLT 3, KYT (a), KYT (b) in Gunung Rapat, G Cheroh in Gunung Cheroh and G Lanno in Gunung Lanno.

3D TLS surveys on the field produce up to a million points that are called 'point clouds'. These point clouds are a representation of the reflected surfaces on the field in $\mathrm{x}, \mathrm{y}$, and $\mathrm{z}$ coordinates system. To produce a 3D model of the study area, raw point clouds data from the scanning need to be registered because it consists of data from multiple scanning positions. The alignment of the point clouds are done by optimizing the distance between two point clouds using Iterative Closest Points (ICP) procedure

TABLE 1. Joints orientation and potential failure for Gunung Lang limestone hills. Joints orientation data were from TLS survey and were extracted by using Coltop 3D software

\begin{tabular}{|c|c|c|c|}
\hline $\begin{array}{l}\text { Slope } \\
\text { GL1 }\end{array}$ & \multicolumn{2}{|c|}{ Joints orientation $\left({ }^{\circ}\right)$} & \multirow{2}{*}{$\begin{array}{l}\text { Potential failure direction }\left(^{\circ}\right) \\
\text { Planar }(090 / 70) \\
\text { Wedge }(055 / 58,115 / 47,125 / 38)\end{array}$} \\
\hline GL1 & $\begin{array}{l}\text { SF } \\
\text { J1 } \\
\text { J2 } \\
\text { J3 } \\
\text { J4 } \\
\text { J5 }\end{array}$ & $\begin{array}{l}70 / 090 \\
67 / 286 \\
68 / 197 \\
59 / 164 \\
69 / 004 \\
59 / 066\end{array}$ & \\
\hline GL2 & $\begin{array}{l}\text { SF } \\
\text { J1 } \\
\text { J2 } \\
\text { J3 } \\
\text { J4 } \\
\text { J5 }\end{array}$ & $\begin{array}{l}80 / 145 \\
54 / 291 \\
74 / 164 \\
79 / 196 \\
73 / 085 \\
73 / 272\end{array}$ & $\begin{array}{l}\text { Planar }(145 / 80) \\
\text { Wedge }(120 / 69,130 / 65,145 / 72)\end{array}$ \\
\hline GL3 & $\begin{array}{l}\text { SF } \\
\text { J1 } \\
\text { J2 } \\
\text { J3 } \\
\text { J4 }\end{array}$ & $\begin{array}{l}80 / 270 \\
69 / 299 \\
66 / 058 \\
50 / 245 \\
80 / 137\end{array}$ & $\begin{array}{l}\text { Planar }(270 / 80) \\
\text { Wedge }(215 / 465,220 / 29,235 / 49)\end{array}$ \\
\hline GL4 & $\begin{array}{l}\mathrm{SF} \\
\mathrm{J} 1 \\
\mathrm{~J} 2 \\
\mathrm{~J} 3 \\
\mathrm{~J} 4 \\
\mathrm{~J} 5\end{array}$ & $\begin{array}{l}80 / 080 \\
69 / 291 \\
75 / 203 \\
75 / 039 \\
68 / 101 \\
74 / 256\end{array}$ & $\begin{array}{l}\text { Planar }(080 / 80) \\
\text { Wedge }(085 / 67,145 / 61)\end{array}$ \\
\hline GL5 & $\begin{array}{l}\text { SF } \\
\text { J1 } \\
\text { J2 } \\
\text { J3 } \\
\text { J4 } \\
\text { J5 } \\
\text { J6 }\end{array}$ & $\begin{array}{l}80 / 100 \\
73 / 310 \\
77 / 163 \\
51 / 141 \\
77 / 084 \\
66 / 280 \\
81 / 259\end{array}$ & $\begin{array}{l}\text { Planar }(100 / 80) \\
\text { Wedge }(080 / 31,120 / 73,175 / 44, \\
160 / 49)\end{array}$ \\
\hline
\end{tabular}


(Besl \& McKay 1992; Chen et al. 1992). Differential Global Positioning System (DGPS) survey is conducted on the field with Real Time Kinematic (RTK) corrections for geo-referencing of the 3D model.

Based on the point cloud data from the scanning of these limestone hills, 3D discontinuity plane models are developed by using RiSCAN Pro and COLTOP 3D software for stability analysis. The kinematic analysis is carried out by using the Markland test procedure and implemented in the Dips Software by Rocscience. The total of 14 rock slope faces is recorded with manual measurements of dip angle and dip direction.

This manual measurement is then used to make a validation with the $3 \mathrm{D}$ TLS measurements. This data validation is carried out according to the method suggested by Cawood et al. (2017); on a control surface which represents the joints and bedding planes of the slope in the field. Multiple dip angle and dip direction measurements are collected on each control surface by using Traditional Compass Clinometer and the same process is repeated by using the overall scan of 3D TLS on the same surface chosen. These data were then plotted as a pole on the stereonet for comparison.

\section{RESULTS}

The slope face, joints orientation and potential failure direction of the slopes are tabulated in Tables 1, 2, and 3. All of the data presented in the table are derived from the TLS survey and extracted by using Coltop 3D software into the stereonet plot. Manually measured data are used for data validation (Figure 4) and comparison which is from slope GL 3 and GL 4 (Figure 5). There are limited manually measured data collected due to site limitations such as thick vegetation covering the joints plane and the inaccessible location of the rock slope itself.

Based on the results, 13 out of 14 rock slope faces from Gunung Lang, Gunung Rapat, Gunung Cheroh, and Gunung Lanno have potential failure of planar and wedge which may occur by dipping perpendicularly away from the slope face. According to Hoek and Bray (1981), a planar failure is likely to occur when a discontinuity dips

TABLE 2. Joints orientation and potential failure for Gunung Rapat limestone hills Potential failure direction $\left(^{\circ}\right)$

\begin{tabular}{|c|c|c|c|}
\hline Slope & \multicolumn{2}{|c|}{ Joints orientation $\left({ }^{\circ}\right)$} & Planar (270/85) \\
\hline KLT 1 (a) & $\begin{array}{l}\text { SF } \\
\text { J1 } \\
\text { J2 } \\
\text { J3 }\end{array}$ & $\begin{array}{l}85 / 270 \\
82 / 040 \\
55 / 074 \\
83 / 251\end{array}$ & Wedge $(330 / 63)$ \\
\hline KLT 1 (b) & $\begin{array}{l}\mathrm{SF} \\
\mathrm{J} 1 \\
\mathrm{~J} 2 \\
\mathrm{~J} 3 \\
\mathrm{~J} 4\end{array}$ & $\begin{array}{l}75 / 280 \\
54 / 082 \\
30 / 224 \\
67 / 122 \\
78 / 356\end{array}$ & No potential failure \\
\hline KLT 1 (c) & $\begin{array}{l}\mathrm{SF} \\
\mathrm{J} 1 \\
\mathrm{~J} 2 \\
\mathrm{~J} 3 \\
\mathrm{~J} 4\end{array}$ & $\begin{array}{l}80 / 280 \\
81 / 299 \\
71 / 162 \\
72 / 111 \\
44 / 091\end{array}$ & $\begin{array}{l}\text { Planar }(280 / 80) \\
\text { Wedge }(220 / 55)\end{array}$ \\
\hline KLT 2 & $\begin{array}{l}\text { SF } \\
\text { J1 } \\
\text { J2 } \\
\text { J3 }\end{array}$ & $\begin{array}{l}83 / 100 \\
64 / 279 \\
80 / 108 \\
71 / 360\end{array}$ & $\begin{array}{l}\text { Planar }(100 / 83) \\
\text { Wedge }(040 / 65)\end{array}$ \\
\hline KLT 3 & $\begin{array}{l}\text { SF } \\
\text { J1 } \\
\text { J2 } \\
\text { J3 }\end{array}$ & $\begin{array}{l}80 / 090 \\
36 / 276 \\
74 / 095 \\
72 / 029\end{array}$ & $\begin{array}{l}\text { Planar }(090 / 80) \\
\text { Wedge }(055 / 70)\end{array}$ \\
\hline KYT (a) & $\begin{array}{l}\text { SF } \\
\mathrm{J} 1 \\
\mathrm{~J} 2 \\
\mathrm{~J} 3 \\
\mathrm{~J} 4\end{array}$ & $\begin{array}{l}80 / 230 \\
80 / 349 \\
81 / 224 \\
83 / 247 \\
76 / 068\end{array}$ & $\begin{array}{l}\text { Planar }(230 / 80) \\
\text { Wedge }(290 / 70)\end{array}$ \\
\hline KYT (b) & $\begin{array}{l}\mathrm{SF} \\
\mathrm{J} 1 \\
\mathrm{~J} 2 \\
\mathrm{~J} 3 \\
\mathrm{~J} 4\end{array}$ & $\begin{array}{l}80 / 260 \\
37 / 112 \\
84 / 244 \\
77 / 212 \\
72 / 042\end{array}$ & $\begin{array}{l}\text { Planar }(260 / 80) \\
\text { Wedge }(330 / 41)\end{array}$ \\
\hline
\end{tabular}


TABLE 3. Joints orientation and potential failure for Gunung Cheroh and Gunung Lanno limestone hills

\begin{tabular}{lccl}
\hline Slope & \multicolumn{1}{c}{ Joints orientation $\left(^{\circ}\right)$} & Potential failure direction $\left(^{\circ}\right)$ \\
\hline G Cheroh & SF & $80 / 180$ & Planar $(180 / 80)$ \\
& J1 & $78 / 050$ & Wedge $(225 / 30,119 / 57)$ \\
& J2 & $79 / 013$ & \\
J3 & $68 / 303$ & \\
G Lanno & J4 & $81 / 143$ & \\
& J5 & $83 / 198$ & \\
& SF & $80 / 230$ & \\
& J1 & $55 / 015$ & \\
& J2 & $84 / 189$ & \\
& J3 & $82 / 242$ & \\
& J4 & $78 / 062$ & \\
\hline
\end{tabular}

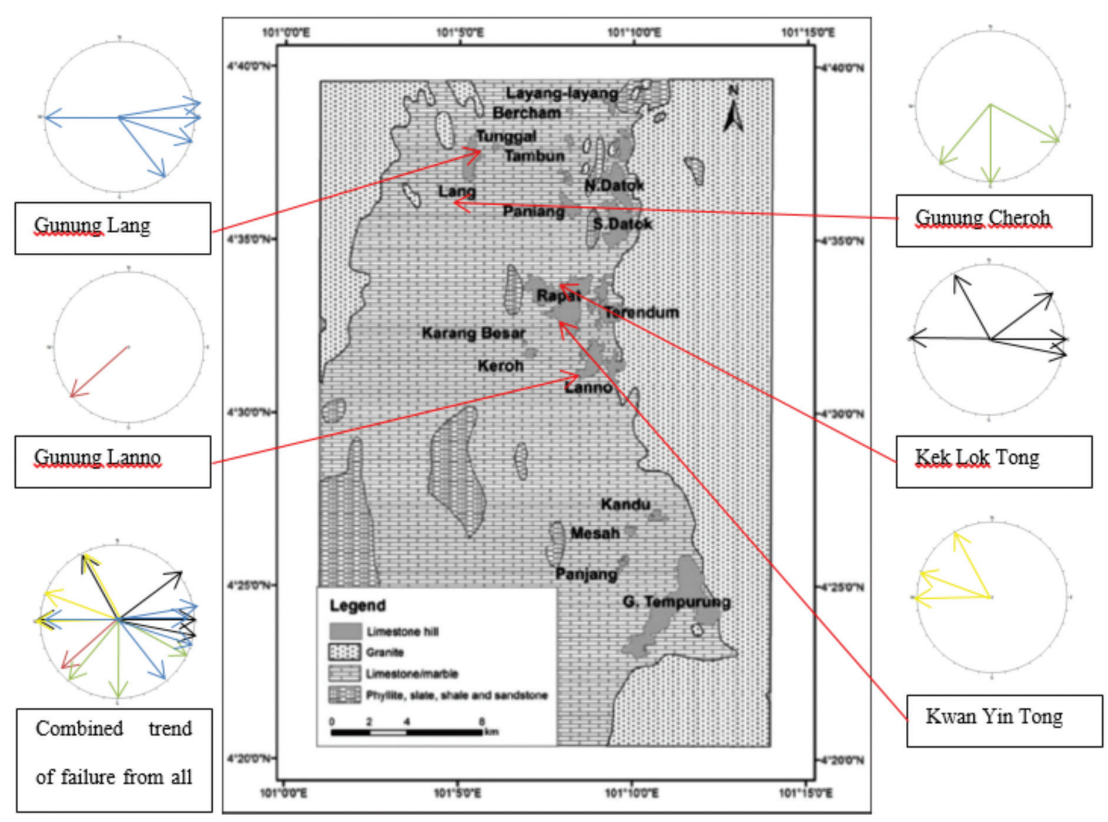

FIGURE 2. Trend of potential failure on the limestone hills based on the kinematic analysis. Arrows with multiple colors represent different limestone hills trend of potential failure. Modified after Norbert et al. (2015)

in the same direction (within $20^{\circ}$ ) as the slope face at an angle gentler than the slope angle, but greater than the friction angle along the failure plane. A wedge failure may occur when the line of intersection of two discontinuities, forming the wedge-shaped block plunges in the same direction as the slope face and the plunge angle is less than the slope angle but greater than the friction angle along the planes of failure (Hoek \& Bray 1981). The kinematic analysis assessment also showed that slope KLT 1 (b) is considered to be safe from any potential failure. Based on the kinematic analysis conducted, the orientation and intersection of joints of possible failures may occur in the direction perpendicular to the slope face. This trend thus shapes the morphology of the limestone hills.

Tables 1, 2, and 3 shows the results of the kinematic analysis assessment of the 14 number of rock slope faces on 4 different limestone hills. Figure 3 shows an example of the effect of the failure trends in controlling the morphology of limestone hills generally. Figure 4 shows comparison and validation between the TLS survey data with the manual compass survey data which has been collected by using method suggested by Cawood et al. (2017) at GL1 slope. 4 control surfaces were selected on the GL1 slope which represents the joint planes and were named CS1, CS2, CS3, and CS4, respectively. Based on the comparison, TLS survey data displayed a deviation of $1^{0}$ to $3^{0}$ from the manual scanline survey data. However, direct comparison without the control surface between manual scanline data with 3D TLS data of overall slope face (Figure 5) shows more deviation in poles plot trends and discontinuity reading. Therefore, different ways of comparing manual and TLS data produce different deviations and results. 

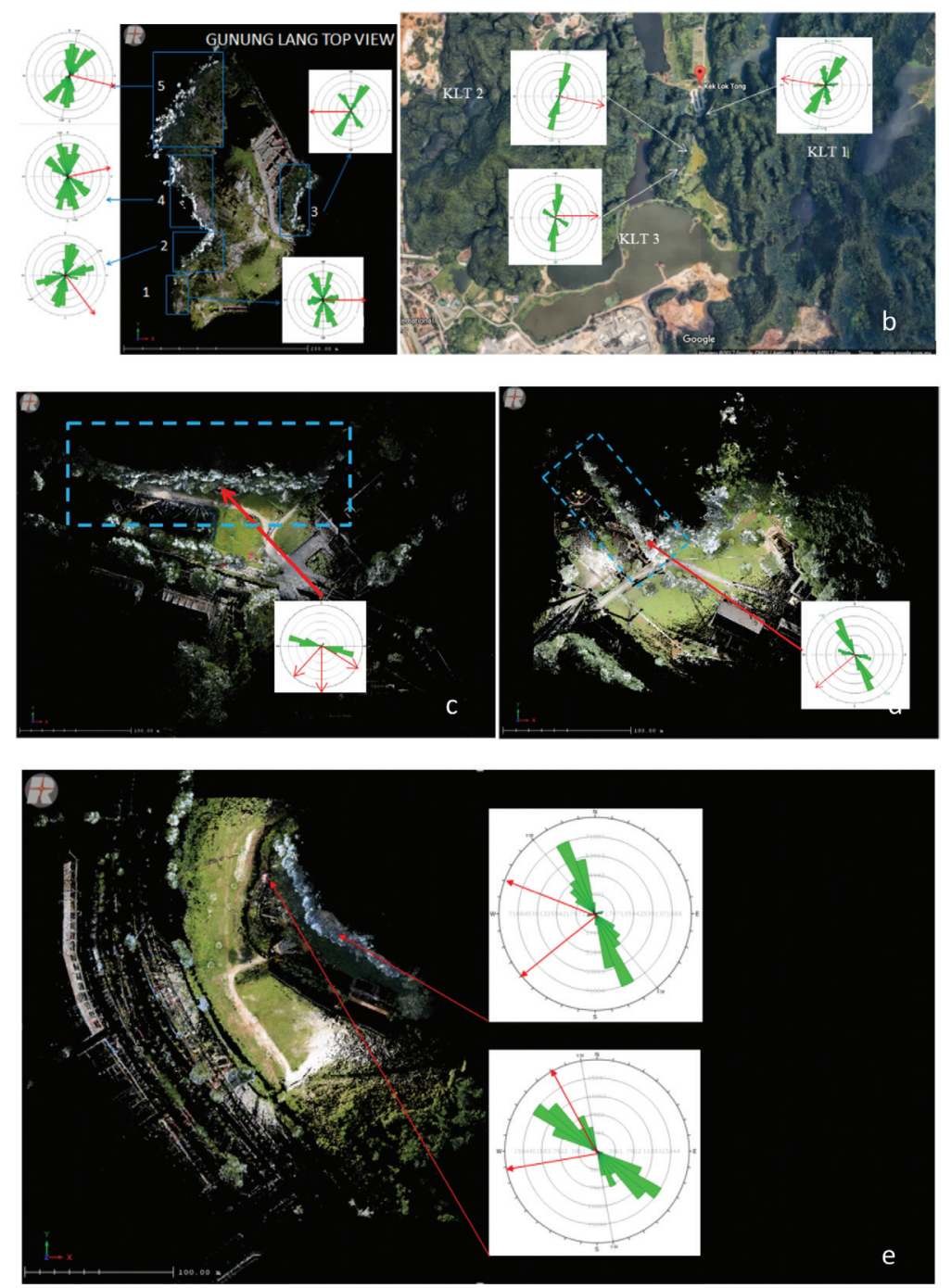

FIGURE 3. Trend of major joint sets align with the morphology of the limestone hills, while the trend of failure (red arrows) occurs perpendicularly from the axes of the limestone hills (a) Gunung Lang (b) Kek Lok Tong (c) Gunung Cheroh (d) Gunung Lanno (e) Kwan Yin Tong

\section{DISCUSSION}

Discontinuity survey such as scanline survey is done manually by compass clinometer directly on the outcrops. However, in massive rock masses such as limestone hills in Kinta Valley, only a limited number of manual measurements can be collected with this conventional method. This is because the surveys are usually concentrated in small areas where direct contact to the slope is accessible, which may not be representative of the entire rock mass. Traditional scanline mapping are affected by obvious drawbacks including sample representatives, accessibility and field safety (Ferrero et al. 2009). According to Sturzenegger and Stead (2009), discontinuities measured in small areas cannot be representative of the whole rock masses. Due to that, this research uses 3D TLS complemented with manual method to assess the slope and joints orientations.

Interpretation of the stereonets showed that the TLS data more accurately described the joint structures of the tested site due to a higher number of measured points (Yiu \& King 2009). Based on the survey data comparison between scanline and 3D TLS (Figure 5) on Gunung Lang, some of the discontinuities set from 3D TLS model correlated weakly with the manual measurements by Goh et al. (2016), while others have fair to strong correlation. An outcome from GL3 slope shows that both manual scanline survey and TLS survey managed to plot 4 sets of joint from the slope. 1 joint set from TLS survey shows strong correlation with joint set from the manual survey, 1 joint set shows fair to weak correlation and the other 2 joints show weak correlation. For the GL4 slope, the manual survey produced a plot with a number of 4 joint sets while TLS survey plotted 5 numbers of joint sets. TLS survey shows 1 number of joint set with strong correlation with manual survey while the other 4 joint sets are weakly correlated. Data from Goh et al. (2016), in Figure 5 show results for manual scanline survey which focuses more at the base of the slope while TLS concentrates on the upper 

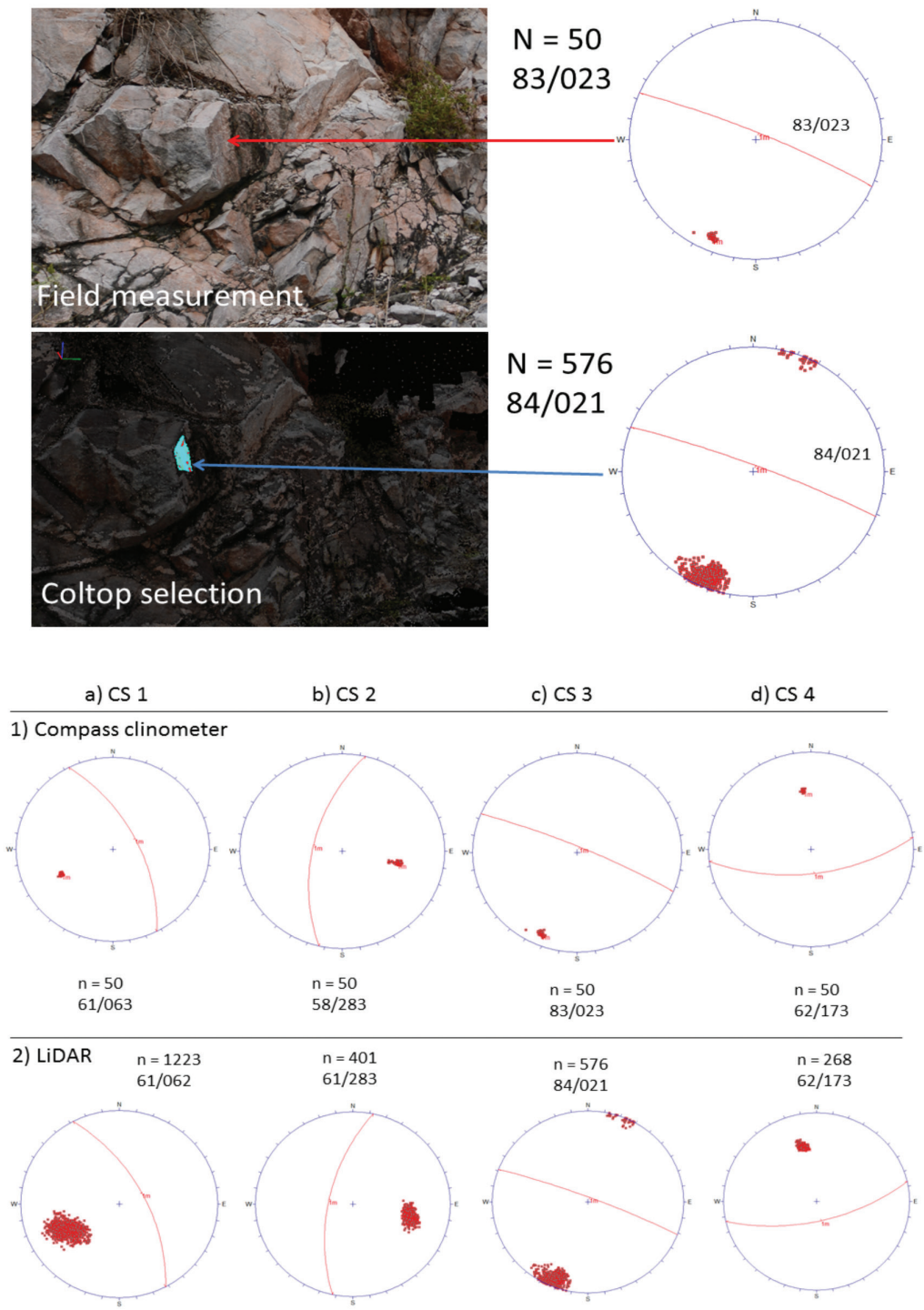

FIGURE 4. 50 manual compass clinometer measurements are collected on each control surface at the field and the same process is repeated with the 3D TLS COLTOP selection. The data are then plotted on the stereonet for comparison and validation. Overall results from four control surfaces a) CS1, b) CS2, c) CS3, and d) CS4 shows data deviation less than $5^{\circ}$ by using method suggested by Cawood et al. (2017)

part and overall slope which is not accessible for manual measurements.

Figure 5 also shows a pole plot of discontinuity trend collected on the same Gunung Lang slope, the only difference is the coverage of the data collection. However, there are also some biases in characterizing the discontinuity by using TLS. According to Sturzenegger and Stead (2009), the observation scale effect, the main function of the distance to the sensor (joint distance bias) and the size of the discontinuity (truncation bias) occurs when small traces are difficult to recognize from 3D point cloud data. Due to that, a cut off value located between 0.2 and $0.6 \mathrm{~m}$ was reported, which may result in over and under-characterizing of discontinuity on the slopes. Furthermore, this weak correlation between both methods may also be due to the persistency and continuity of the joints measured. Discontinuity measured at the base of the slope may not continuously be extended to the upper part of the slope and some of it may disappear due to weathering, this explained the reason why the method suggested by (Cawood et al. 2017) produced lesser deviation.

Despite all of these limitations, TLS was able to provide a large number of discontinuity orientation data from the lower part to the upper part of the slope for stability analysis as compared to manual measurement. It is important for one to understand and acknowledge the limitations of 3D TLS survey before choosing it for analysis technique. Ignoring these limitations will produce false data and errors. This shows the importance of implementing both manual scanline method and 3D TLS as both compliments its own strengths and limitations in assessing slope from a different scale (Figure 6). According to Spreafico et al. (2015), the 


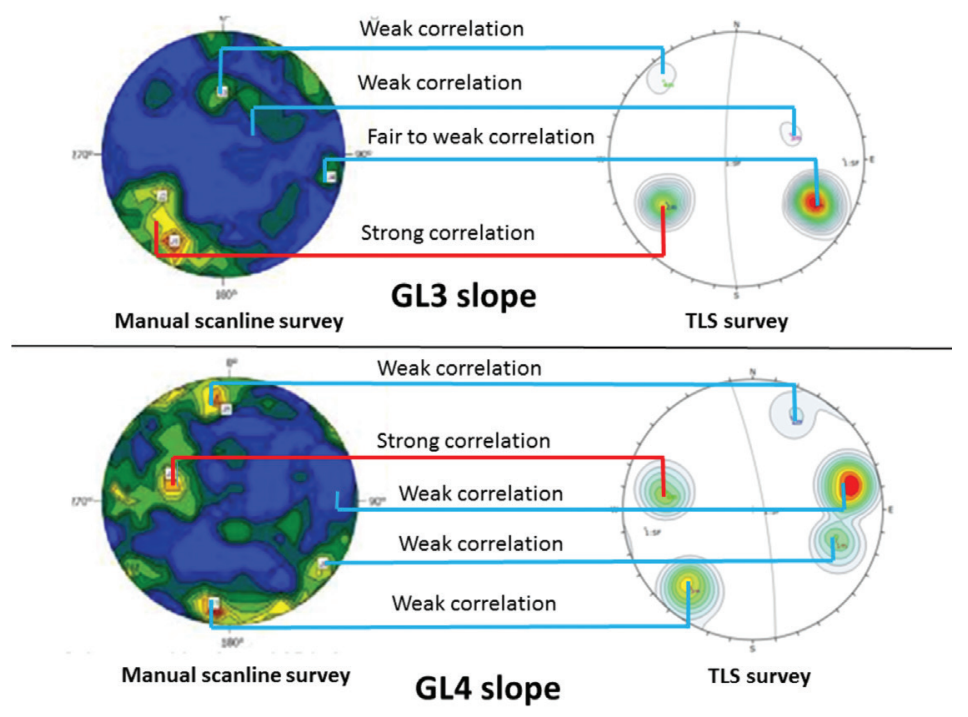

FIGURE 5. Comparison between 3D TLS poles plot data with scanline survey poles data by Goh et al. (2016)

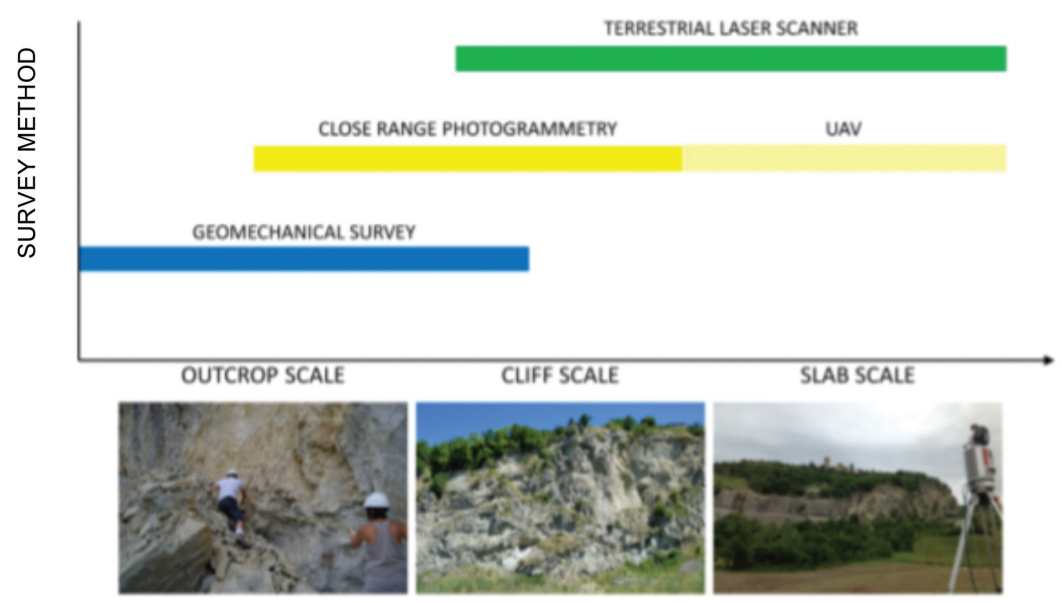

FIGURE 6. Indication of the scale at which the use of different technique is considered to be convenient. After Spreafico et al. (2015)

conventional survey techniques are more applicable at the outcrop scale, while when dealing with a large cliff or with an entire rock slab, the TLS technique is to be preferred.

In terms of structural geology of the study area, a straight $26 \mathrm{~km}$ long scarp is found on the eastern flank of the Kledang Range. It is suggestive of a major fault and several smaller faults have been observed at the eastern side of the Kinta Valley (Norbert et al. 2015). According to Muhammad and Tjia (2003), the trend of Kinta Valley karst structure is mainly along the $310-350^{\circ}$ with minor directions of about $030^{\circ}, 040^{\circ}, 055^{\circ}, 070^{\circ}$, and $085^{\circ}$. These trends originate from tectonic stresses and controls the formation of certain karst features such as dolines, wangs, caves and collapse.

According to Chen et al. (2019), tectonic stress is an important external load that affects the stability of a slope by increasing the sliding force of the sliding body towards a free surface. Numerous studies on karst concluded that structure plays a major role in determining the formation of karst features (Rossi 1989; Song 1989). This is supported by Tjia (1969); observation on positive and negative lineaments in several karst regions showing that they represent fracture direction which was agreed by Escher (1931), who was of the opinion that the dolines are located at the intersection of fractures.

All 14 number of slopes assessed in this research shows 17 potential failure trends in various directions except for slope KLT 1 (b) which has no potential failure detected. The major trend of possible failure based on overall studied slopes are towards east direction as seen in Figure 2. Gunung Lang shows major potential failure trend towards east direction, Gunung Lanno towards southwest, Kek Lok Tong shows trends towards east, Kwan Yin Tong towards west, and finally Gunung Cheroh with three direction of failure which are south, southwest and southeast direction. 


\section{CONCLUSION}

Based on the results, Terrestrial Laser Scanning survey helps rock mass characterization on steep sided limestone hills in Kinta Valley. However, some of the discontinuities measured by field measurements are not detected due to sampling under small exposure plane, or due to weathering that changed the orientation of discontinuity and some of the location of the slope is inaccessible for manual scanline measurements.

Another limitation from 3D TLS is the determination of the cluster of poles plot of discontinuity is often uncertain and depending on user judgement, which may lead to error, especially for users with less experience in rock characterization. This research is only focusing on the effects of joints orientation which causes rock slope failure. However, rock slope failure may also occur due to other factors such as weathering and dissolution of the limestone hills. Furthermore, the effect of blasting may also increase and trigger the rockfall in the area. Slope monitoring is essential in order to ensure the condition of the slope from time to time.

\section{ACKNOWLEDGEMENTS}

The authors would like to thank Muhamad Asyraf Azmi, Muhammad Aliff Shahrim and Iman Muhammad for the assistance in the field. This study is funded by FRGS research grant FP014-2014B. Special thanks to Reservoir Modelling and MicroCT Laboratory, Department of Geology for allowing the use of LiDar equipment and associated softwares. This lab is funded by grant awarded from Jawatankuasa Tetap Kewangan University of Malaya.

\section{REFERENCES}

Agliardi, F. \& Crosta, G.B. 2003. High resolution threedimensional numerical modelling of rockfalls. International Journal of Rock Mechanics and Mining Sciences 40(4): 455-471. https://doi.org/https://doi.org/10.1016/S13651609(03)00021-2.

Besl, P.J. \& McKay, N.D. 1992. Method for registration of 3-D shapes. Sensor Fusion IV: Control Paradigms and Data Structures 1611: 586-606.

Cawood, A.J., Bond, C.E., Howell, J.A., Butler, R.W. \& Totake, Y. 2017. LiDAR, UAV or compass-clinometer? Accuracy, coverage and the effects on structural models. Journal of Structural Geology 98: 67-82.

Chen, S., Goh, T.L., Han, L. \& Tovele, G.S. 2019. Effects of tectonic stresses and structural planes on slope deformation and stability at the Buzhaoba open Pit Mine, China. Sains Malaysiana 48(2): 317-324.

Chen, Y. \& Medioni, G. 1992. Object modelling by registration of multiple range images. Image and Vision Computing 10(3): 145-155.

Dunning, S.A., Massey, C.I. \& Rosser, N.J. 2009. Structural and geomorphological features of landslides in the Bhutan Himalaya derived from terrestrial laser scanning. Geomorphology 103(1): 17-29.

Escher, B.G. 1931. The Goenoeng Sewoe and the problem of the Karst in the Tropics. Acts of the XXIII. Dutch Natural and Medical Congress. pp. 259-261.
Ferrero, A.M., Forlani, G., Roncella, R. \& Voyat, H.I. 2009. Advanced geostructural survey methods applied to rock mass characterization. Rock Mechanics and Rock Engineering 42(4): 631-665.

Ghani, M.F.A., Tuan Rusli, M., Abdul Ghani, R. \& Ailie, S.S. 2018. A systematic approach of rock slope stability assessment: A case study at Gunung Kandu, Gopeng, Perak, Malaysia. Sains Malaysiana 47(7): 1413-1421.

Ghani, M.F.A., Norbert, S., Goh, T.L., Tuan Rusli, M. \& Abdul Ghani, R. 2016. Study of lineament density in potential evaluation of rock fall in Kinta Valley. Sains Malaysiana 45(12): 1887-1896.

Goh, T.L., Ainul Mardhiyah, M.R., Nur Amanina, M., Abdul Ghani, R., Nur Ailie, S.S. \& Tuan Rusli, M. 2016. Rock slope stability assessment using slope mass rating (SMR) method: Gunung Lang Ipoh Malaysia. Scholar Journal of Engineering and Technology 4(4): 185-192.

Guzzetti, F., Cardinali, M., Reichenbach, P., Cipolla, F., Sebastiani, C., Galli, M. \& Salvati, P. 2004. Landslides triggered by the 23 November 2000 rainfall event in the Imperia Province, Western Liguria, Italy. Engineering Geology 73(3-4): 229-245.

Hoek, E. \& Bray, J. 1981. Rock Slope Engineering. 3rd ed London: The Institution of Miningand Metallurgy.

Ingham, F.T. \& Bradford, E.F. 1960. The Geology and Mineral Resources of the Kinta Valley, Perak. No. 9. Federation of Malaya: Geological Survey.

Lato, M.J. \& Vöge, M. 2012. Automated mapping of rock discontinuities in 3D LiDAR and photogrammetry models. International Journal of Rock Mechanics and Mining Sciences 54: 150-158.

Marquinez, J., Duarte, R.M., Farias, P. \& Sanchez, M.J. 2003. Predictive GIS-based model of rockfall activity in mountain cliffs. Natural Hazards 30(3): 341-360.

Muhammad, R.F. \& Tjia, H.D. 2003. The morphostructures of Kinta Valley karst. Bulletin of the Geological Society of Malaysia 46: 319-328.

Norbert, S., Ghani, M.F.A., Azimah, H., Goh, T.L., Abdul Ghani, R., Noraini, S., Tuan Rusli, T.M. \& Lee, K.E. 2015. Assessment of rockfall potential of limestone hills in the Kinta Valley. Journal of Sustainability Science and Management 10(2): 24-34.

Nur Amanina, M., Goh, T.L., Ainul Mardhiyah, M.R., Abdul Ghani, R., Ailie, S.S., Norbert, S., Noraini, S., Lee, K.E. \& Tuan Rusli, M. 2018. The geomechanical strength of carbonate rock in Kinta valley, Ipoh, Perak Malaysia. AIP Conference Proceedings 1940: 020046-1 - 020046-8. doi: 10.1063/1.5027961.

Priest, S.D. 1993. The collection and analysis of discontinuity orientation data for engineering design, with examples. In Rock Testing and Site Characterization, edited by Hudson, J.A. Oxford: Pergamon Press. pp. 167-192.

Priest, S.D. \& Hudson, J. 1981. Estimation of discontinuity spacing and trace length using scanline surveys. International Journal of Rock Mechanics and Mining Sciences \& Geomechanics Abstracts 18(3): 183-197.

Romana, M. 1985. New adjustment ratings for application of Bieniawski classification to slopes. Proceedings of the International Symposium on Role of Rock Mechanics, Zacatecas, Mexico. pp. 49-53.

Rossi, G. 1986. Karst and structure in tropical areas: The Malagasi example. In New Direction in Karst: Proceedings of the Anglo-French Symposium, edited by Paterson, K. \& Sweeting M.M. Norwich: Geo Books. 1983: 189-212. 
Song, L.H. 1989. Geological structure: An important factor controlling karst development. In New Direction in Karst: Proceedings of the Anglo-French Symposium. Paterson, K. \& Sweeting M.M. Norwich: Geo Books. 1983: 165-174.

Spreafico, M.C., Perotti, L., Cervi, F., Bacenetti, M., Bitelli, G., Girelli, V.A., Mandanici, E., Tini, M.A. \& Borgatti, L. 2015. Terrestrial remote sensing techniques to complement conventional geomechanical surveys for the assessment of landslide hazard: The San Leo case study (Italy). European Journal of Remote Sensing 48(1): 639-660.

Sturzenegger, M. \& Stead, D. 2009. Close-range terrestrial digital photogrammetry and terrestrial laser scanning for discontinuity characterization on rock cuts. Engineering Geology 106(3-4): 163-182.

Tan, B.K. 1988. Geologi Kejuruteraan Kawasan Sekitaran Ipoh, Perak. (Engineering geology of the Ipoh area, Perak). Laporan Akhir Projek Penyelidikan No.7/86, Sept. 1988, UKM.p. 74.

Tjia, Hong Djin. 1969. Slope development in tropical karst. Zeitschrift fuer Geomorphologie 13(3): 260-66.

Yiu, K. \& King, B. 2009. Stereonet data from terrestrial laser scanner point clouds. Survey Review 41(314): 324-338. doi: 10.1179/003962609X45173.

Muhammad Afiq Ariff Hellmy, Ros Fatihah Muhammad*, Mustaffa Kamal Shuib, Ng Tham Fatt, Wan Hasiah Abdullah \& Ralph Kugler

Department of Geology, Faculty of Science

University of Malaya

50603 Kuala Lumpur, Federal Territory

Malaysia
Aishah Abu Bakar

Department of Civil Engineering, Faculty of Engineering

University of Malaya

50603 Kuala Lumpur, Federal Territory

Malaysia

*Corresponding author; email: rosfmuhammad@um.edu.my

Received: 20 April 2019

Accepted: 15 August 2019 